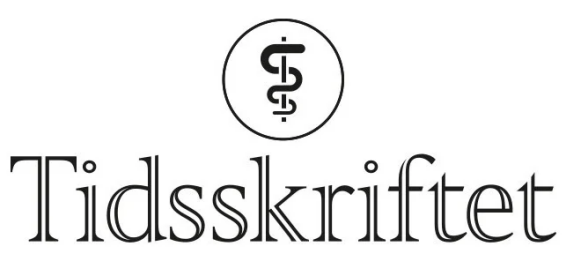

\title{
Estimert glomerulær filtrasjonshastighet som mål på nyrefunksjon
}

\author{
KLINISK OVERSIKT
}

\section{KRISTIAN HELDAL}

hkri@ous-hf.no

Seksjon for nyremedisin

Avdeling for transplantasjonsmedisin

Oslo universitetssykehus, Rikshospitalet

Han har bidratt med ide og utarbeiding, revisjon og godkjenning av manus.

Kristian Heldal er ph.d., master i helseadministrasjon, spesialist i indremedisin og nyresykdommer og seksjonsoverlege.

Forfatteren har fylt ut ICMJE-skjemaet og oppgir ingen interessekonflikter.

\section{ANDERS ÅSBERG}

Seksjon for nyremedisin

Avdeling for transplantasjonsmedisin

Oslo universitetssykehus, Rikshospitalet

og

Farmasøytisk institutt

Det matematisk-naturvitenskapelige fakultet

Universitetet i Oslo

Han har bidratt med utarbeiding, revisjon og godkjenning av manus.

Anders Åsberg er cand.pharm., ph.d., daglig leder av Nyrefysiologisk laboratorium og Norsk nyreregister og professor II.

Forfatteren har fylt ut ICMJE-skjemaet og oppgir ingen interessekonflikter.

\section{SADOLLAH ABEDINI}

Nyremedisinsk seksjon

Medisinsk klinikk

Sykehuset i Vestfold

Han har bidratt med utarbeiding, revisjon og godkjenning av manus.

Sadollah Abedini er ph.d., spesialist i indremedisin og nyresykdommer og overlege.

Forfatteren har fylt ut ICMJE-skjemaet og oppgir ingen interessekonflikter.

\section{TROND GEIR JENSSEN}

Seksjon for nyremedisin

Avdeling for transplantasjonsmedisin

Oslo universitetssykehus, Rikshospitalet

og

Institutt for klinisk medisin

Det medisinske fakultet

Universitetet i Oslo

og

Institutt for klinisk medisin 
UiT - Norges arktiske universitet

Han har bidratt med utarbeiding, revisjon og godkjenning av manus.

Trond Geir Jenssen er dr.med., spesialist i indremedisin og nyresykdommer, overlege og professor II.

Forfatteren har fylt ut ICMJE-skjemaet og oppgir ingen interessekonflikter.

\section{ANNA VARBERG REISAETER}

Seksjon for nyremedisin

Avdeling for transplantasjonsmedisin

Oslo universitetssykehus, Rikshospitalet

Hun har bidratt med utarbeiding, revisjon og godkjenning av manus.

Anna Varberg Reisæter er dr.med., spesialist i indremedisin og nyresykdommer og overlege.

Forfatteren har fylt ut ICMJE-skjemaet og oppgir ingen interessekonflikter.

\section{STEIN BERGAN}

Avdeling for farmakologi

Oslo universitetssykehus, Rikshospitalet

og

Farmasøytisk institutt

Det matematisk-naturvitenskapelige fakultet,

Universitetet i Oslo

Han har bidratt med utarbeiding, revisjon og godkjenning av manus.

Stein Bergan er cand.pharm., dr.philos., forsker og professor II.

Forfatteren har fylt ut ICMJE-skjemaet og oppgir ingen interessekonflikter.

\section{ANDERS HARTMANN}

Seksjon for nyremedisin

Avdeling for transplantasjonsmedisin

Oslo universitetssykehus, Rikshospitalet

og

Institutt for klinisk medisin

Det medisinske fakultet

Universitetet i Oslo

Han har bidratt med ide og utarbeiding, revisjon og godkjenning av manus.

Anders Hartmann er dr.med., spesialist i indremedisin og nyresykdommer, pensjonert overlege og professor emeritus.

Forfatteren har fylt ut ICMJE-skjemaet og oppgir ingen interessekonflikter.

\section{Estimert glomerulær filtrasjonshastighet er etablert som klinisk rutinemål for nyrefunksjon, men estimatet har begrensninger og kan ikke brukes i alle kliniske situasjoner. Estimert glomerulær filtrasjonshastighet har en høy variasjonskoeffisient, og ved avvik i pasientens høyde, vekt eller muskelmasse kan estimatet bli unøyaktig. Hvis det er avgjørende å ha et nøyaktig mål på nyrefunksjonen, kan man måle glomerulær filtrasjonshastighet ved hjelp av en eksogen substans.}

Nyrene har mange funksjoner, slik som utskilling av vannløselige avfallsstoffer og regulering av væske- og elektrolyttbalanse, syre- og basestatus, blodtrykk og endokrine funksjoner. Den primære nyrefunksjonen - filtrering av urin - måles gjennom glomerulær filtrasjonshastighet (forkortet GFR etter engelsk glomerular filtration rate) og oppgis i mL/min.

Vi gjennomgår her begrepet GFR og beskriver nytte og begrensninger ved bruk av estimert GFR i klinisk sammenheng. Artikkelen er basert på ikke-systematiske søk i databasen PubMed, internasjonale anbefalinger og forfatternes kliniske erfaring. 
GFR kan måles som clearance av eksogene substanser, omtalt som målt GFR (mGFR), eller det kan estimeres med formler basert på konsentrasjonen av endogene stoffer som kreatinin eller cystatin C i tillegg til kjønn og alder, og blir da omtalt som estimert GFR (eGFR). Siden variablene som inngår i formlene kan hentes fra laboratoriestystemet, er det mulig å utgi estimert GFR automatisk som kroppsoverflatenormalisert verdi ( $\left.\mathrm{mL} / \mathrm{min} / 1,73 \mathrm{~m}^{2}\right)$, uten at man eksplisitt kjenner pasientens kroppsoverflate. Med kjennskap til pasientens høyde og vekt kan kroppsoverflaten beregnes, og estimert GFR kan dermed konverteres til absolutt GFR, som er pasientens reelle GFR oppgitt i $\mathrm{mL} / \mathrm{min}$.

Den første formelen som ble tatt i bruk for automatisk angivelse av estimert GFR var basert på data fra MDRD-studien (modification of diet in renal disease), der målt GFR ble bestemt som clearance av ${ }^{125}$ I-iotalamat (1). Da alle pasientene i MDRD-studien hadde nyresykdom, var det få personer i datamaterialet med normal nyrefunksjon, og følgelig hadde estimatet dårligere nøyaktighet ved høy GFR. Siden den gang er det utviklet flere forbedrede formler, basert på større pasientpopulasjoner som også inkluderer personer med normal nyrefunksjon samt både eldre og yngre personer (는 $)$. De fleste laboratorier utgir nå estimert GFR basert på CKD-EPIformelen fra 2009 (chronic kidney disease epidemiology collaboration) (2).

Formlenes nøyaktighet angis gjerne som andelen av estimater som befinner seg innenfor $\pm 30 \%$ av den målte verdien (P30). Selv de beste formlene oppnår imidlertid ikke P30 særlig høyere enn $80 \%$, hvilket innebærer at en femtedel av de estimerte GFR-verdiene avviker fra de målte GFR-verdiene med mer enn 30 \% (므).

\section{Hva kan vi bruke estimert GFR til?}

I de fleste kliniske situasjoner er estimert GFR et nyttig og tilstrekkelig mål for nyrefunksjonen.

\section{DIAGNOSTISERE OG GRADERE NYRESYKDOM}

Estimert GFR benyttes i dag som et standardisert mål for nyrefunksjonen og inngår i gradering av kronisk nyresykdom (ㄱ) (tabell 1). Alle pasienter med estimert GFR $<60$ mL/min/1,73 m² med varighet lengre enn tre måneder har kronisk nyresykdom i stadium 3 eller høyere. Ved estimert GFR $\geq 60 \mathrm{~mL} / \mathrm{min} / 1,73 \mathrm{~m}^{2}$ betinger diagnosen andre tegn på nyreskade, som albuminuri, patologisk urinsediment, tegn på tubulær dysfunksjon, unormale funn ved histopatologisk eller radiologisk undersøkelse, eller gjennomgått nyretransplantasjon.

\section{Tabell 1}

Stadieinndeling av kronisk nyresykdom basert på estimert GFR (7). Forutsetter varighet på over tre måneder.

\begin{tabular}{|ll|}
\hline Sykdomsstadium & Estimert GFR $\left(\mathrm{mL} / \mathrm{min} / 1,73 \mathrm{~m}^{2}\right)$ \\
\hline Nyrefrisk & $\geq 60$ uten markør på nyreskade \\
\hline Stadium 1 & $>90+$ markør på nyreskade \\
\hline Stadium 2 & $60-89+$ markør på nyreskade \\
\hline Stadium 3 & $30-59$ \\
\hline Stadium 4 & $15-29$ \\
\hline Stadium 5 & $<15$ \\
\hline
\end{tabular}


Pasienter med kronisk nyresykdom behøver regelmessig oppfølging. Ved diagnosetidspunktet vurderes årsaken til sykdommen, og deretter bør pasienten kontrolleres med tanke på progresjon og komplikasjoner. Estimert GFR bør beregnes minst én gang årlig, slik at henvisning til spesialist kan skje på optimalt tidspunkt. I spesialisthelsetjenesten brukes endring av estimert GFR som støtte for planlegging av nyreerstattende behandling (dialyse eller nyretransplantasjon).

\section{HENVISNING TIL NYRESPESIALIST}

Tidlig henvisning til nyrespesialist gir mulighet for å gi pasientopplæring i god tid før pasienten må starte nyreerstattende behandling. Alle norske nyreavdelinger benytter en tverrfaglig tilnærming til pasienter med kronisk nyresykdom for å gi pasienten tilstrekkelig kunnskap til å velge mellom forskjellige behandlingsalternativer. I tillegg gjør tidlig henvisning det mulig å utrede pasienten for nyretransplantasjon og starte konservativ uremibehandling samt gjøre forberedelser til start av dialysebehandling før situasjonen blir akutt. Basert utelukkende på grad av nyrefunksjonsnedsettelse anbefales det derfor at pasienter med estimert GFR $<30$ $\mathrm{mL} / \mathrm{min} / 1,73 \mathrm{~m}^{2}$ bør henvises til nyrespesialist (으). Dette er også nedfelt i Helsedirektoratets anbefaling for behandling av nyresykdom hos personer med diabetes (ㅁ). Pasienter med raskt fallende estimert GFR (> $\left.5 \mathrm{~mL} / \mathrm{min} / 1,73 \mathrm{~m}^{2} / a ̊ r\right)$ bør henvises til nyrespesialist uansett utgangsnivå.

\section{VURDERING AV KARDIOVASKULAER RISIKO}

Prevalensen av kronisk nyresykdom er over 10 \% både i Norge og USA $(\underline{10}, \underline{11})$, og prevalensen øker med alderen. Selv lettere grader av nedsatt nyrefunksjon er en sterk og selvstendig risikofaktor for hjerte- og karsykdommer og død $(\underline{12}, \underline{13})$. Bestemmelse av estimert GFR kan derfor bidra til å identifisere personer med økt risiko for kardiovaskulær sykdom, slik at disse kan motta nødvendig kardioprotektiv behandling (12).

\section{Begrensninger ved bruk av estimert GFR}

Tabell 2 angir kliniske situasjoner der estimert GFR er mindre nøyaktig og man derfor må vurdere andre metoder for å bestemme nyrefunksjonen.

\section{Tabell 2}

Kliniske situasjoner der estimert GFR kan være unøyaktig og man bør vurdere andre metoder for å bestemme GFR.

\begin{tabular}{|lll|}
\hline Klinisk situasjon & Estimert GFR & Alternativ metode \\
\hline Akutt nyresvikt & Kan ikke benyttes & $\begin{array}{l}\text { Evaluere andre kriterier } \\
\text { Urinproduksjon } \\
\text { Endring i kreatininkonsentrasjon }\end{array}$ \\
\hline Lav GFR & $\begin{array}{l}\text { Overestimerer GFR } \\
\text { Ekstrarenal } \\
\text { kreatininutskillelse } \\
\text { Økt andel som sekreres i } \\
\text { tubuli }\end{array}$ & Måle GFR \\
\hline Lav muskelmasse & Overestimerer GFR & $\begin{array}{l}\text { Cystatin C-basert estimat } \\
\text { Måle GFR }\end{array}$ \\
\hline Høy muskelmasse & Underestimerer GFR & $\begin{array}{l}\text { Cystatin C-basert estimat } \\
\text { Måle GFR }\end{array}$ \\
\hline Liten kroppsoverflate & Overestimerer GFR & $\begin{array}{l}\text { Beregne absolutt GFR } \\
\text { Måle GFR }\end{array}$ \\
\hline
\end{tabular}




\begin{tabular}{|c|c|c|}
\hline Klinisk situasjon & Estimert GFR & Alternativ metode \\
\hline Stor kroppsoverflate & Underestimerer GFR & $\begin{array}{l}\text { Beregne absolutt GFR } \\
\text { Måle GFR }\end{array}$ \\
\hline $\begin{array}{l}\text { Dosering av legemidler } \\
\text { som elimineres i nyrene }\end{array}$ & $\begin{array}{l}\text { Avviker fra GFR pga. } \\
\text { avvikende kroppsoverflate }\end{array}$ & $\begin{array}{l}\text { Beregne absolutt GFR } \\
\text { Måle GFR }\end{array}$ \\
\hline $\begin{array}{l}\text { Dosering av legemidler } \\
\text { etter kreatinin-clearance }\end{array}$ & $\begin{array}{l}\text { Kreatinin-clearance } \\
\neq \text { GFR }\end{array}$ & $\begin{array}{l}\text { Beregne kreatinin-clearance } \\
\text { Cockcroft og Gaults formel } \\
\text { Urinsamling }\end{array}$ \\
\hline Før nyredonasjon & $\begin{array}{l}\text { Nødvendig med nøyaktig } \\
\text { angivelse av nyrefunksjonen }\end{array}$ & Måle GFR \\
\hline Barn & Unøyaktig estimat & $\begin{array}{l}\text { Benytte egen formel for barn } \\
\text { Måle GFR }\end{array}$ \\
\hline Eldre & Unøyaktig estimat & $\begin{array}{l}\text { Benytte egen formel for eldre } \\
\text { Cystatin C-basert estimat } \\
\text { Måle GFR }\end{array}$ \\
\hline $\begin{array}{l}\text { Spesielle etniske } \\
\text { grupper (f.eks. asiater) }\end{array}$ & Unøyaktig estimat & $\begin{array}{l}\text { Cystatin C-basert estimat } \\
\text { Måle GFR }\end{array}$ \\
\hline Graviditet & Unøyaktig estimat & $\begin{array}{l}\text { Cystatin C-basert estimat } \\
\text { Måle GFR }\end{array}$ \\
\hline
\end{tabular}

\section{AKUTT NYRESVIKT}

Formlene for estimert GFR er basert på målinger på pasienter med stabil nyrefunksjon. Av den grunn kan estimert GFR ikke benyttes ved raskt fall i GFR. Akutt nyreskade (AKI, acute kidney injury), som er en vanlig akutt- og intensivmedisinsk tilstand, vurderes i stedet ved endringer i kreatininverdi og grad av oliguri (14). Akutt nyreskade omtales ikke nærmere her.

\section{AVVIK I MUSKELMASSE}

Formlene for beregning av estimert GFR er utviklet med data fra større studier der man både har analysert kreatininverdi og målt GFR med eksogen substans (1, 2, 2). Følgelig er formlene representative for den populasjonen de er utledet fra. Ekstrapolering til andre populasjoner eller individer som avviker mye fra populasjonens middelverdier, kan være beheftet med begrensninger. Kreatininverdien samvarierer med muskelmassen, og pasienter med lav muskelmasse kan ha normal kreatininkonsentrasjon i plasma og dermed tilsynelatende normal estimert GFR, selv om målt GFR er betydelig redusert. Ved lav GFR øker også andelen kreatinin som sekreres i tubuli, noe som ytterligere bidrar til overestimering av GFR. Siden økende alder er forbundet med avtagende muskelmasse, må alder vurderes sammen med andre forhold som kan påvirke produksjon og utskillelse av kreatinin, som fysisk aktivitet og medikamenter (f.eks. trimetoprim og cimetidin), når man skal tolke estimert GFR.

For å redusere problemet med avvikende muskelmasse er det utviklet formler for estimert GFR basert på cystatin C, enten alene eller i kombinasjon med kreatinin $(\underline{2}, \underline{3})$.

Kombinasjonsformlene har noe høyere nøyaktighet (모), men utfordringen er at en del laboratorier ikke utfører cystatin C-analyser.

\section{Behov for andre og mer nøyaktige mål for GFR}

Fordi de fleste formlene for estimert GFR rapporterer kroppsoverflatenormaliserte verdier $\left(\mathrm{mL} / \mathrm{min} / 1,73 \mathrm{~m}^{2}\right)$, kan estimatet avvike vesentlig fra pasientens absolutte GFR. Dette har spesielt betydning i forbindelse med dosering av legemidler. 
Absolutt GFR (mL/min) er lavere enn estimert GFR ( $\mathrm{mL} / \mathrm{min} / 1,73 \mathrm{~m}^{2}$ ) hos personer med liten kroppsoverflate, og høyere hos personer med stor kroppsoverflate. Avviket er numerisk størst for store personer. Medikamentutskillelsen bestemmes av absolutt GFR. Hvis estimert GFR benyttes som grunnlag for dosering hos små personer, kan pasienten overdoseres med økt risiko for toksisitet, mens store personer risikerer behandlingssvikt. Et velkjent klinisk eksempel på dette er digoksin, som lett kan overdoseres til små personer dersom man ikke korrigerer for kroppsoverflate.

Det er en utbredt, men feilaktig, oppfatning at kreatinin-clearance og GFR er det samme. I tillegg til å filtreres i glomeruli, sekreres kreatinin i proksimale tubuli, og følgelig blir kreatininclearance høyere enn GFR (트). Siden forskjellen øker med avtagende nyrefunksjon, er dette spesielt viktig ved alvorlig nedsatt nyrefunksjon. For mange medikamenter (f.eks.

direktevirkende orale antikoagulasjonsmidler (DOAK), digoksin, aminoglykosider og valganciklovir) er Felleskatalogens doseringsanbefaling ved nedsatt nyrefunksjon basert på kreatinin-clearance, og ikke GFR. I disse tilfellene kan dosering på bakgrunn av estimert GFR medføre underdosering. Samling av døgnurin for å bestemme renal kreatinin-clearance er arbeidskrevende og beheftet med feilkilder. Et alternativ er å benytte Cockcroft og Gaults formel, som estimerer absolutt kreatinin-clearance i mL/min (므). Også denne formelen er imidlertid beheftet med feilkilder, blant annet fordi den ble utviklet på grunnlag av ikkestandardisert kreatininanalyse.

VURDERING FØR NYREVEVSRESEKSJON ELLER NYREDONASJON

Når det er behov for et nøyaktig mål for nyrefunksjonen, må man måle GFR som clearance av en eksogen filtrasjonsmarkør. Aktuelle markører er radioaktivt merkede stoffer som ${ }^{99}$ Tc-DTPA (technetium-dietylentriaminpentaacetat) eller ${ }^{51}$ Cr-EDTA (krom-etylendiamintetraacetat). En annen mye brukt markør er røntgenkontrastmiddelet joheksol, som i dag regnes som gullstandard for måling av GFR (토). Måling av joheksol-clearance innebærer at man injiserer en gitt mengde intravenøst, og deretter måler konsentrasjonen av joheksol i plasma i gjentatte prøver på gitte tidspunkter. Ved nedsatt nyrefunksjon må man ta prøver i opptil et døgn etter injeksjonen. Vi har nylig lansert en ny populasjonskinetisk metode, hvor det ikke er nødvendig å

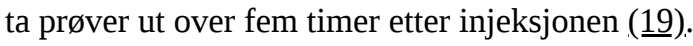

\section{Konklusjon}

I dag benyttes estimert GFR rutinemessig i klinisk praksis. Estimatet er adekvat til de fleste kliniske formål, men forutsetter stabil nyrefunksjon og kan derfor ikke benyttes ved akutt nyresvikt. Ved dosering av legemidler som utskilles renalt og doseres etter GFR, må man ut fra legemiddelets toksisitet og effektivitet vurdere om det er nødvendig å måle GFR eller beregne en absolutt verdi for GFR ved å korrigere estimert GFR for faktisk kroppsoverflate.

Artikkelen er fagfellevurdert.

\section{LITTERATUR}

1. Levey AS, Bosch JP, Lewis JB et al. A more accurate method to estimate glomerular filtration rate from serum creatinine: a new prediction equation. Ann Intern Med 1999; 130: 461-70. [PubMed][CrossRef]

2. Levey AS, Stevens LA, Schmid CH et al. A new equation to estimate glomerular filtration rate. Ann Intern Med 2009; 150: 604-12. [PubMed][CrossRef]

3. Schaeffner ES, Ebert N, Delanaye P et al. Two novel equations to estimate kidney function in persons aged 70 years or older. Ann Intern Med 2012; 157: 471-81. [PubMed][CrossRef] 
4. Pottel H, Delanaye P, Schaeffner E et al. Estimating glomerular filtration rate for the full age spectrum from serum creatinine and cystatin C. Nephrol Dial Transplant 2017; 32: 497-507. [PubMed][CrossRef]

5. Nyman U, Grubb A, Larsson A et al. The revised Lund-Malmö GFR estimating equation outperforms MDRD and CKD-EPI across GFR, age and BMI intervals in a large Swedish population. Clin Chem Lab Med 2014; 52: 815-24. [PubMed][CrossRef]

6. Porrini E, Ruggenenti P, Luis-Lima S et al. Author Correction: Estimated GFR: time for a critical appraisal. Nat Rev Nephrol 2019; 15: 121. [PubMed][CrossRef]

7. Stevens PE, Levin A et al. Evaluation and management of chronic kidney disease: synopsis of the kidney disease: improving global outcomes 2012 clinical practice guideline. Ann Intern Med 2013; 158: 825-30. [PubMed][CrossRef]

8. Summary of Recommendation Statements. Kidney Int Suppl (2011) 2013; 3: 5-14. [PubMed] [CrossRef]

9. Nasjonal faglig retningslinje for diabetes. Oslo: Helsedirektoratet, 2016. https://www.helsedirektoratet.no/retningslinjer/diabetes Lest 5.9.2021.

10. Centers for Disease Control and Prevention (CDC). Prevalence of chronic kidney disease and associated risk factors-United States, 1999-2004. MMWR Morb Mortal Wkly Rep 2007; 56: 161-5. [PubMed]

11. Annual report Norwegian Renal Registry 2019 Oslo: Norsk nyreregister, 2020. https://www.nephro.no/nnr/A_RSRAPPORT_NNR_2019.pdf Lest 5.10.2021.

12. Gansevoort RT, Correa-Rotter R, Hemmelgarn BR et al. Chronic kidney disease and cardiovascular risk: epidemiology, mechanisms, and prevention. Lancet 2013; 382: 339-52. [PubMed][CrossRef]

13. Tonelli M, Muntner P, Lloyd A et al. Impact of age on the association between CKD and the risk of future coronary events. Am J Kidney Dis 2014; 64: 375-82. [PubMed][CrossRef]

14. Section 2: AKI Definition. Kidney Int Suppl (2011) 2012; 2: 19-36. [PubMed][CrossRef]

15. Eriksen BO, Mathisen UD, Melsom T et al. The role of cystatin C in improving GFR estimation in the general population. Am J Kidney Dis 2012; 59: 32-40. [PubMed][CrossRef]

16. Fernandez-Prado R, Castillo-Rodriguez E, Velez-Arribas FJ et al. Creatinine clearance is not equal to glomerular filtration rate and cockcroft-gault equation is not equal to CKD-EPI collaboration equation. Am J Med 2016; 129: 1259-63. [PubMed][CrossRef]

17. Cockcroft DW, Gault MH. Prediction of creatinine clearance from serum creatinine. Nephron J 1976; 16: 31-41. [PubMed][CrossRef]

18. Eriksen BO, Schaeffner E, Melsom T et al. Comparability of plasma iohexol clearance across population-based cohorts. Am J Kidney Dis 2020; 76: 54-62. [PubMed][CrossRef]

19. Åsberg A, Bjerre A, Almaas R et al. Measured GFR by utilizing population pharmacokinetic methods to determine iohexol clearance. Kidney Int Rep 2019; 5: 189-98. [PubMed][CrossRef]

Publisert: 22. desember 2021. Tidsskr Nor Legeforen. DOI: 10.4045/tidsskr.21.0501

Mottatt 16.6.2021, første revisjon innsendt 8.9.2021, godkjent 5.10.2021.

Publisert under åpen tilgang CC BY-ND. Lastet ned fra tidsskriftet.no 26. april 2023. 